\title{
ANALISIS KESALAHAN SISWA DALAM MENYELESAIKAN SOAL RELASI DAN FUNGSI DI KELAS VII SMP NEGERI 4 BALAI JAYA
}

\author{
Winda Lestari ${ }^{1}$, Kartini ${ }^{2 *}$ \\ Program Pascasarjana, Pendidikan Matematika, Fakultas Keguruan dan IImu \\ Pendidikan, Universitas Riau, Pekanbaru, Indonesia \\ *winda.lestari1776@grad.unri.ac.id
}

Received: January $31^{\text {st }}, 2021$

Revised: February $28^{\text {th }}, 2021$

Accepted: February $28^{\text {th }}, 2021$

\begin{abstract}
The concept of relations and functions in the school mathematics curriculum was first accepted by students in grade VIII. In evaluating students' understanding of the concept of relations and function material, there are mistakes made by students. Errors that occur can be in the form of misconceptions, principles, and operating errors. This study aims to describe the types of errors in solving the material relations and functions of the VIII grade students of SMP Negeri 4 Balai Jaya in the odd semester of the 2020/2021 school year. This type of research is descriptive-qualitative research, with the test as a data collection instrument. The subjects in this study were 27 students of class VIIIA. The results showed that on average $60 \%$ of students made misconceptions, $51 \%$ of students made mistakes in principle and $63 \%$ of students made operational errors. Students have not been able to present relations correctly using arrow diagrams, Cartesian diagrams and consecutive sets of pairs. Students also still have difficulty distinguishing relations and functions. In the matter of functions, the use of steps in manipulating algebraic calculations carried out by students is not quite right.
\end{abstract}

Keywords: relations and functions; the analysis of mistakes; types of mistake..

\section{PENDAHULUAN}

Matematika sebagai salah satu cabang ilmu, memainkan peranan yang sangat penting dalam membangun kehidupan manusia yang berkualitas. Menurut Susanto (2016, p.183) matematika merupakan salah satu disiplin ilmu untuk meningkatkan kemampuan berfikir dan berargumentasi, solusi dalam penyelesaian masalah sehari-hari, serta memberikan dukungan dalam pengembangan ilmu pengetahuan dan teknologi. Matematika merupakan salah satu mata pelajaran wajib dalam Kurikulum 2013 yang diberikan kepada siswa dari jenjang Sekolah Dasar sampai dengan Sekolah Menengah Atas. Dalam proses pembelajaran tidak selalu berlangsung lancar dan berhasil, mengingat kemampuan anak yang berbeda-beda mengakibatkan keberhasilan anak dalam pembelajaran juga berbeda-beda. Kesulitan yang dialami siswa ini 
dapat disebabkan oleh banyak faktor, seperti faktor internal yang berasal dari dalam diri anak maupun faktor eksternal yang berasal dari luar diri anak. Kesulitan siswa memungkinkan terjadinya kesalahan dalam menyelesaikan soal pada materi tertentu seperti penelitian-penelitian terdahulu yang menunjukkan beragam kesulitan dan kesalahan siswa dalam memahami konsep matematika (Lely, Putra, \& Syahrilfuddin, 2020; Syafitri, Putra, \& Noviana, 2020).

Kesalahan menurut Kamus Besar Bahasa Indonesia (2007, p.982) berasal dari kata dasar "salah" yang artinya tidak benar, tidak betul atau keliru. Jadi, kesalahan dalam menyelesaikan soal matematika berarti siswa tidak benar dalam menyelesaikan soal matematika. Sedangkan menurut Rosyidi dalam Wijaya dan Masriyah (2012, p.2) mendefinisikan kesalahan sebagai suatu bentuk penyimpangan terhadap hal yang dianggap benar atau prosedur yang ditetapkan sebelumnya. Jika hal ini dibiarkan maka tujuan pembelajaran tidak akan terlaksana dengan baik. Untuk itu dibutuhkan analisis kesalahan secara mendetail agar dapat diketahui kesalahan-kesalahan siswa tersebut.

Analisis kesalahan sebagai prosedur kerja mempunyai langkah-langkah tertentu. Menurut Tarigan (1988) yang dikutip dalam Ni'mah (2009, p.20), berbagai langkah-langkah tersebut adalah: a) Mengumpulkan data kesalahan-kesalahan, b) Mengidentifikasi kesalahan dan mengklasifikasikan kesalahan, c) Memperingatkan kesalahan, d) Menjelaskan kesalahan, e) Memperkirakan daerah rawan kesalahan, dan f) Mengoreksi kesalahan.

Menurut Jarmita (2015) kekeliruan-kekeliruan atau kesalahan pada konsep dasar matematika akan menyebabkan siswa kesulitan dalam mempelajari konsep berikutnya, sehingga akan sulit pula dalam mempelajari pelajaran matematika. Hudojo (2005, p.3) menyatakan bahwa matematika berkenaan dengan ide-ide atau konsep-konsep abstrak yang tersusun secara hirarkis dan penalarannya deduktif. Oleh karenanya, dalam proses pembelajaran matematika tidak semua siswa selalu berhasil mencapai tujuan pembelajaran. Jika ada saja siswa yang tidak dapat belajar, ini berarti siswa mengalami kesulitan yang berakibat pada terjadinya kesalahan dalam menyelesaikan soal-soal matematika. Penyebab kesalahan yang dilakukan oleh siswa dalam menyelesaikan soal-soal dapat dilihat dari berbagai hal. 
Jenis-jenis kesalahan menurut Sukirman dalam Amir (2015) yaitu: (1) kesalahan konsep, yaitu kesalahan yang berkaitan dengan penggunaan konsep yang digunakan dalam materi, (2) kesalahan prinsip, yaitu kesalahan yang berkaitan dengan hubungan dua atau lebih objek, (3) kesalahan operasi, yaitu kesalahan dalam melakukan perhitungan. Jadi dapat dikatakan bahwa kesalahan prinsip dan kesalahan operasi termasuk dalam kesalahan bukan konsep.

Sementara Kastolan dalam Sulistyaningsih, dkk (2012) membagi jenis kesalahan ke dalam kesalahan konsep dan kesalahan prosedural. Kesalahan konsep menurut Kastolan adalah kesalahan yang dilakukan siswa dalam menafsirkan istilah, konsep, dan prinsip, atau salah dalam menggunakan istilah, konsep, dan prinsip. Kesalahan prosedural adalah kesalahan dalam menyusun langkah-langkah hirarkis dan sistematis untuk menjawab soal.

Berdasarkan pendapat Sukirman dalam Amir (2015) dan Kastolan dalam Sulistyaningsih, dkk (2012) memiliki kesamaan makna, tapi berbeda dalam kualifikasi jenis kesalahannya, diidentifikasi bahwa kesalahan konsep menurut Kastolan mengandung unsur kesalahan prinsip menurut Sukirman. Serta, kesalahan prosedural menurut Kastolan dapat diketahui melalui kesalahan konsep, prinsip, dan operasi menurut Sukirman dari langkah-langkah penyelesaian soal. Dengan kata lain, jenis kesalahan menurut Sukriman dalam Amir (2015) lebih rinci dan sekaligus mengetahui jenis-jenis kesalahan menurut Kastolan dalam Sulistyaningsih, dkk (2012). Oleh karena itu jenis kesalahan siswa dalam menyelesaikan soal relasi dan fungsi pada penelitian ini dikelompokkan menjadi tiga yakni:

1. Kesalahan Konsep, yaitu kesalahan yang berkaitan dengan penggunaan konsep yang digunakan dalam materi. Dalam penelitian ini indikator dari kesalahan kosep yakni a) kesalahan memberikan contoh dan bukan contoh relasi atau fungsi; dan b) ketidaktepatan menggunakan model, diagram, dan simbol-simbol seperti mempresentasikan fungsi seperti tidak menamai diagram dan tidak menggambar bundaran untuk masing-masing himpunan pada saat mempresentasikan dalam bentuk diagram panah.

2. Kesalahan Prinsip, yaitu kesalahan yang berkaitan dengan hubungan dua atau lebih objek. Kesalahan dalam menggunakan rumus-rumus atau sebuah 
kesalahan dalam mengaitkan beberapa fakta dan beberapa konsep yang berhubungan. Indokator kesalahan prinsip dalam penelitian ini yakni salah dalam menafsirkan dan menggunakan rumus banyaknya pemetaan dari $A$ ke $B$ dan salah dalam menentukan nilai fungsi.

3. Kesalahan Operasi

Yaitu kesalahan yang dilakukan siswa dikarenakan ketidakmampuan melakukan proses perhitungan dengan tepat dan benar serta kesalahan memanipulasi aljabar. Indikator kesalahan teknik dalam penelitian ini yakni a) kesalahan siswa dalam melakukan perhitungan yang tidak tepat; b) ketidakmampuan dalam melakukan perhitungan dalam bentuk aljabar pada saat mencari nilai fungsi.

\section{METODE PENELITIAN}

Penelitian ini merupakan penelitian deskriptif kualitatif untuk mengungkap secara mendalam jenis-jenis kesalahan yang dilakukan siswa dalam menyelesaikan soal relasi dan fungsi. Penelitian ini dilaksanakan di SMP Negeri 4 Balai Jaya pada kelas VIIIA pada semester ganjil tahun ajaran 2020/2012. Penelitian ini dilakukan pada 27 siswa kelas VIIIA SMP Negeri 4 Balai Jaya tahun pelajaran 2020/2012, setelah mempelajari materi pokok relasi dan fungsi.

Teknik pengumpulan data yang digunakan dalam penelitian ini adalah tes yang digunakan untuk mengidentifikasi kesalahan siswa dalam menyelesaikan soal menurut Sukriman dalam Amir (2015). Analisis data yang dilakukan pada penelitian ini menurut Milles dan Huberman yang dikutip oleh Sugiyono (2005, p.91) yaitu: (1) reduksi data (data reduction), (2) penyajian data (data display) dan (3) penarikan kesimpulan atau verifikasi (conclusion drawing / verification).

Langkah-langkah dalam analisis data sebagai berikut: (1) Reduksi data, yaitu yaitu kegiatan yang mengacu kepada proses mentransformasikan data mentah yang tertulis di lapangan, menyeleksi, menyederhanakan dan mengelompokkan. Tahap reduksi data dalam penelitian ini meliputi: (a) Melakukan observasi dan menyusun hasil observasi; (b) Mengoreksi hasil pekerjaan siswa yang akan digunakan untuk menentukan subjek penelitian (2) Penyajian data, yaitu sekumpulan informasi tersusun yang memberi kemungkinan penarikan 
kesimpulan dan pengambilan tindakan. Tahap penyajian data dalam penelitian ini meliputi: Menyajikan hasil pekerjaan siswa yang telah telah dipilih sebagai subjek penelitian (3) Verifikasi (pengecekan) data dan penarikan kesimpulan, yaitu dilakukan selama kegiatan analisis berlangsung sehingga diperoleh suatu kesimpulan akhir.

\section{HASIL DAN PEMBAHASAN}

\section{Hasil Penelitian}

Penelitian dilaksanakan di SMP Negeri 4 Balai Jaya kelas VIII A. Penelitian ini dimulai dengan pemberian tes tertulis yang berupa 5 soal tes uraian yang diberikan pada semua siswa kelas VIII A SMP Negeri 4 Balai Jaya yang berjumlah 27 siswa. Berikut persentase rata-rata skor siswa yang menjawab dengan benar pada setiap soal:

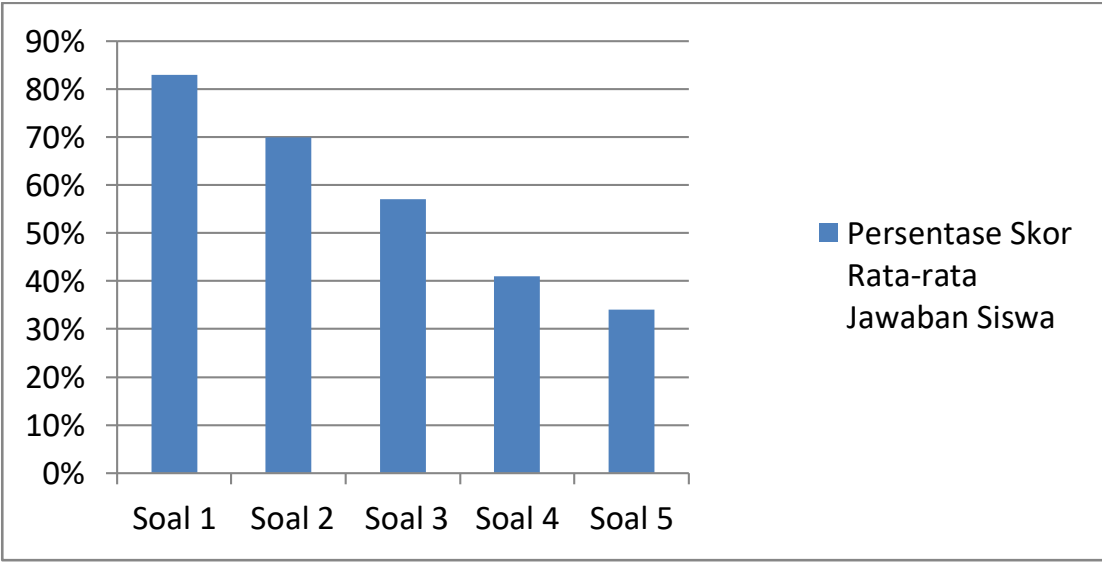

Gambar 1. Persentase Rata-rata Skor Siswa Menjawab Dengan Benar

Berdasarkan diagram diatas dapat dilihat bahwa pada soal 1 hampir seluruh siswa menjawab dengan benar yaitu sebanyak $83 \%$ siswa menjawab dengan benar. Pada soal 2 terdapat 70\% siswa menjawab dengan benar dan pada soal 3 sebanyak $57 \%$ siswa menjawab dengan benar. Sedangkan soal 4 dan soal 5 lebih dari setengah siswa menjawab salah yaitu $41 \%$ dan $34 \%$ siswa yang hanya menjawab betul soal 4 dan soal 5. Dilihat dari presentase tersebut beberapa siswa tentu melakukan kesalahan dalam menjawab soal relasi dan fungsi yang telah diberikan. Setelah dianalisis berikut kesalahan-kesalahan siswa dalam menjawab soal: 


\section{Kesalahan pada soal 1}

Pada soal 1 terdapat 11 siswa yang melakukan kesalahan konsep, jika dipersetasekan yaitu $41 \%$. Selanjutnya 3 siswa atau $11 \%$ yang melakukan kesalahan prinsip serta tidak ada yang melakukan kesalahan operasi. Kesalahankesalahan tersebut dapat dilihat dari gambar salah satu jawaban siswa berikut:

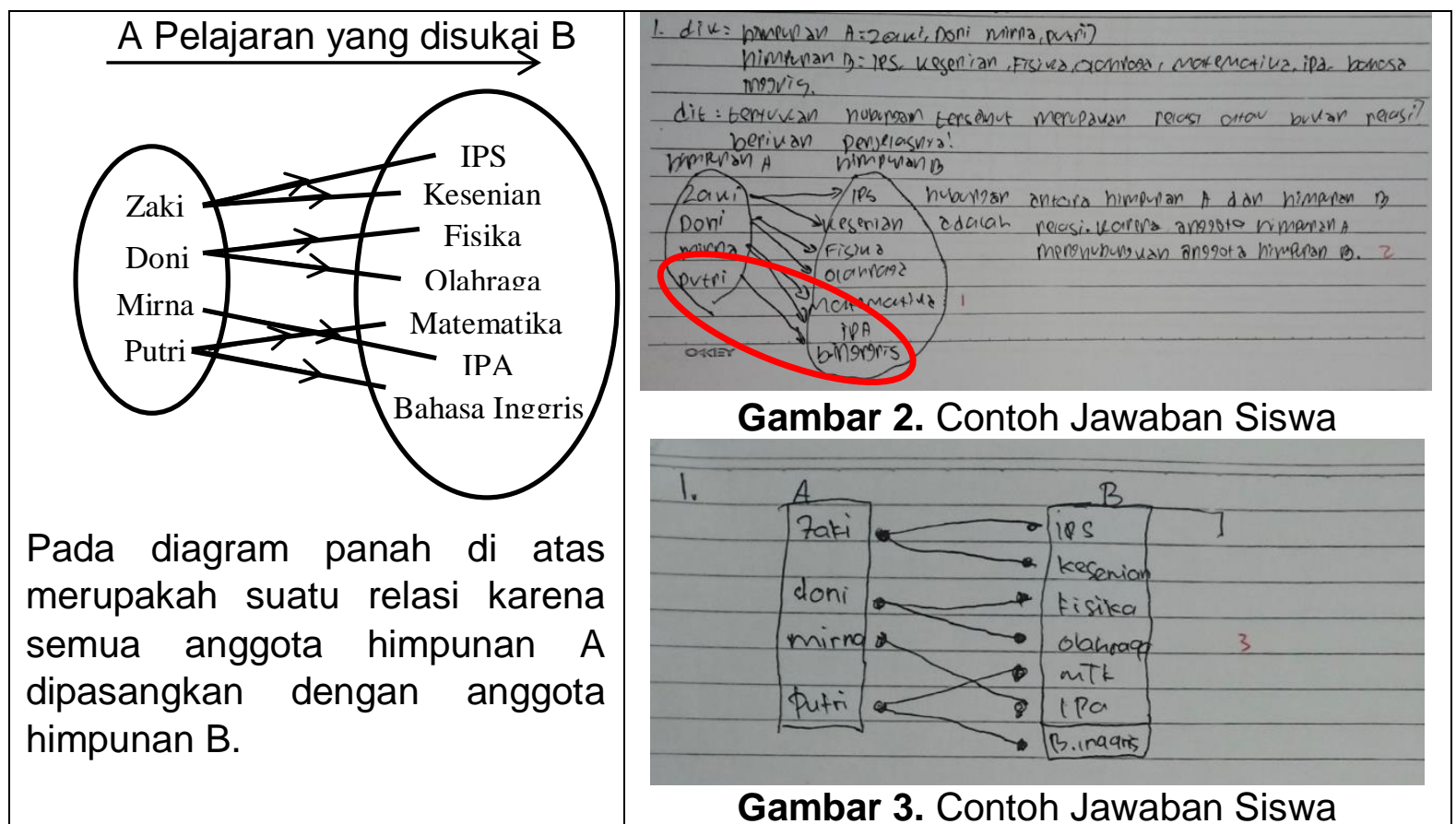

Dapat dilihat pada gambar 2 siswa melakukan kesalahan prinsip dimana siswa salah dalam memetakan A ke B. terlihat siswa memetakan anggota himpunan A yaitu Putri ke anggota himpunan B yaitu bahasa Inggris, seharusnya pemetaan anggota himpunan $A$ yaitu Putri ke himpunan $B$ yaitu matematika dan bahasa inggris. Pada gambar 3 terlihat siswa telah memetakan himpunan A ke $B$ dengan benar tetapi siswa tidak menyebutkan apakah hubungan tersebut termasuk relasi atau bukan relasi yang artinya siswa melakukan kesalahan konsep. Hal ini disebabkan siswa tidak paham apa yang ditanya dari soal yg diberikan ataupun siswa memang tidak paham konsep dari relasi tersebut.

\section{Kesalahan pada soal 2}


Sama halnya pada soal 1 kesalahan yang dilakukan siswa pada soal 2 yaitu terdapat 18 siswa yang melakukan kesalahan konsep, jika dipersetasekan yaitu $67 \%$. Selanjutnya 6 siswa atau $22 \%$ yang melakukan kesalahan prinsip serta tidak ada yang melakukan kesalahan operasi. Kesalahan-kesalahan tersebut dapat dilihat dari gambar salah satu jawaban siswa berikut:

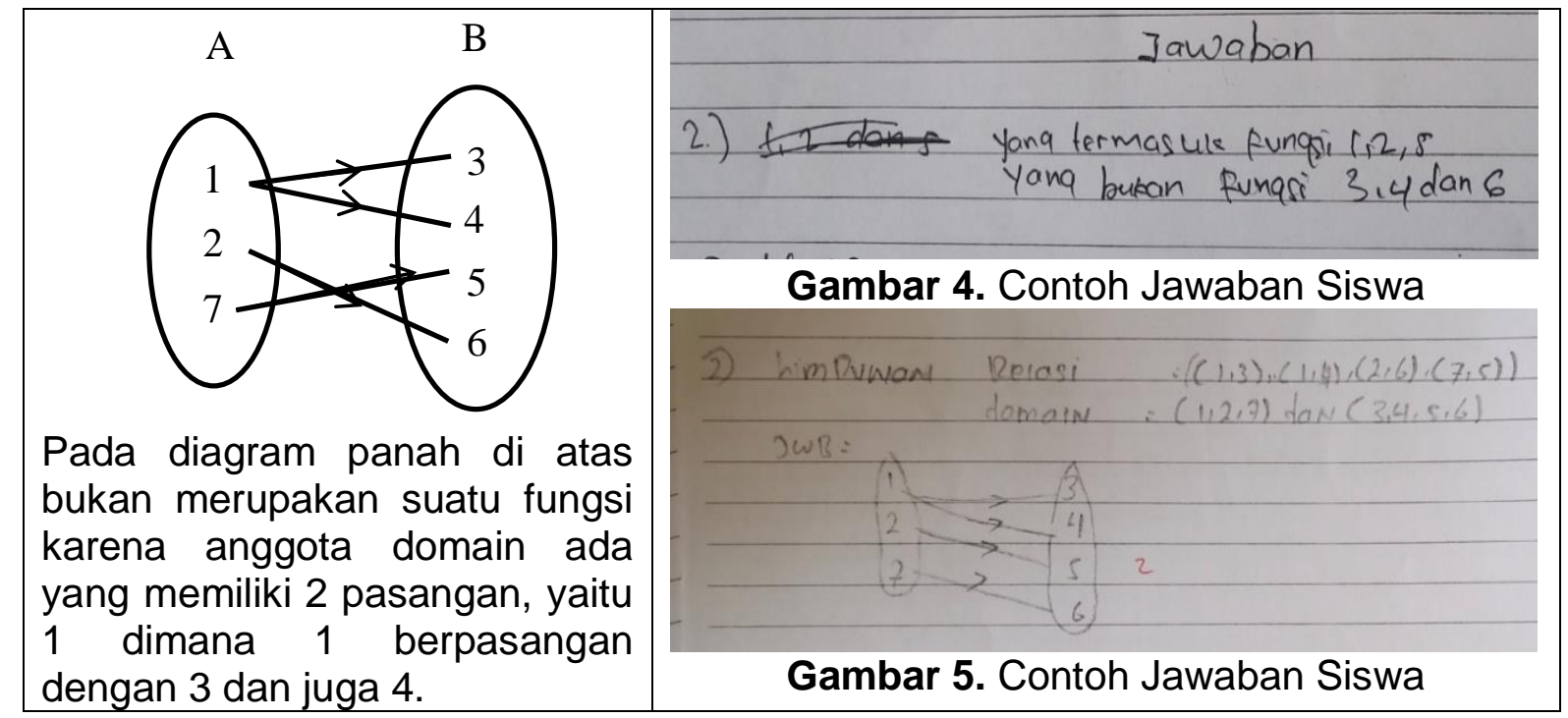

Berdasarkan kedua gambar di atas dapat dilihat bahwa siswa melakukan kesalahan konsep dan prinsip. Dimana pada gambar 4 siswa salah dalam menggambarkan diagram panah dari yang diketahui pada soal, kesalahan dalam menggambarkan diagram panah tersebut merupakan salah satu indikator pada kesalahan prinsip. Jika telaah dari jawaban siswa pada gambar pertama siswa menyebutkan "yang termasuk fungsi 1,2,5. Yang bukan termasuk fungsi 3,4 dan 6" artinya siswa tidak paham akan konsep relasi dan fungsi. Siswa tidak dapat membedakan antara fungsi dan bukan fungsi, kesalahan tersebut merupakan salah satu indikator kesalahan konsep.

Selanjutnya pada gambar 5 siswa telah memetakan relasi yang diketahui pada soal dengan benar tetapi siswa tersebut tidak menyebutkan apakah digram panah yang telah dia tulis merupakan fungsi atau bukan fungsi serta tidak menyertaka alasannya. Kesalahan seperti ini banyak dilakukan oleh siswa, hal ini disebabkan siswa tidak paham apa yang ditanya dari soal yg diberikan ataupun siswa memang tidak paham konsep dari fungsi tersebut.

\section{Kesalahan pada soal 3}


Bentuk soal 3 terbagi menjadi dua yaitu a dan b, namun keduanya saling berhubungan. Jika pertanyaan a dijawab dengan salah maka pertanyaan $b$ juga ikut salah. Hampir semua siswa kurang teliti menjawab pertanyaan a sehingga mempengaruhi jawaban mereka pada pertanyaan b. Pada soal 3 terdapat 24 siswa yang melakukan kesalahan konsep atau jika dipersentasekan yaitu $89 \%$. Terdapat 20 siswa atau 74\% siswa yang melakukan kesalahan prinsip serta 9 siswa atau 33\% siswa melakukan kesalahan operasi. Kesalahan-kesalahan tersebut dapat dilihat dari gambar salah satu jawaban siswa berikut:

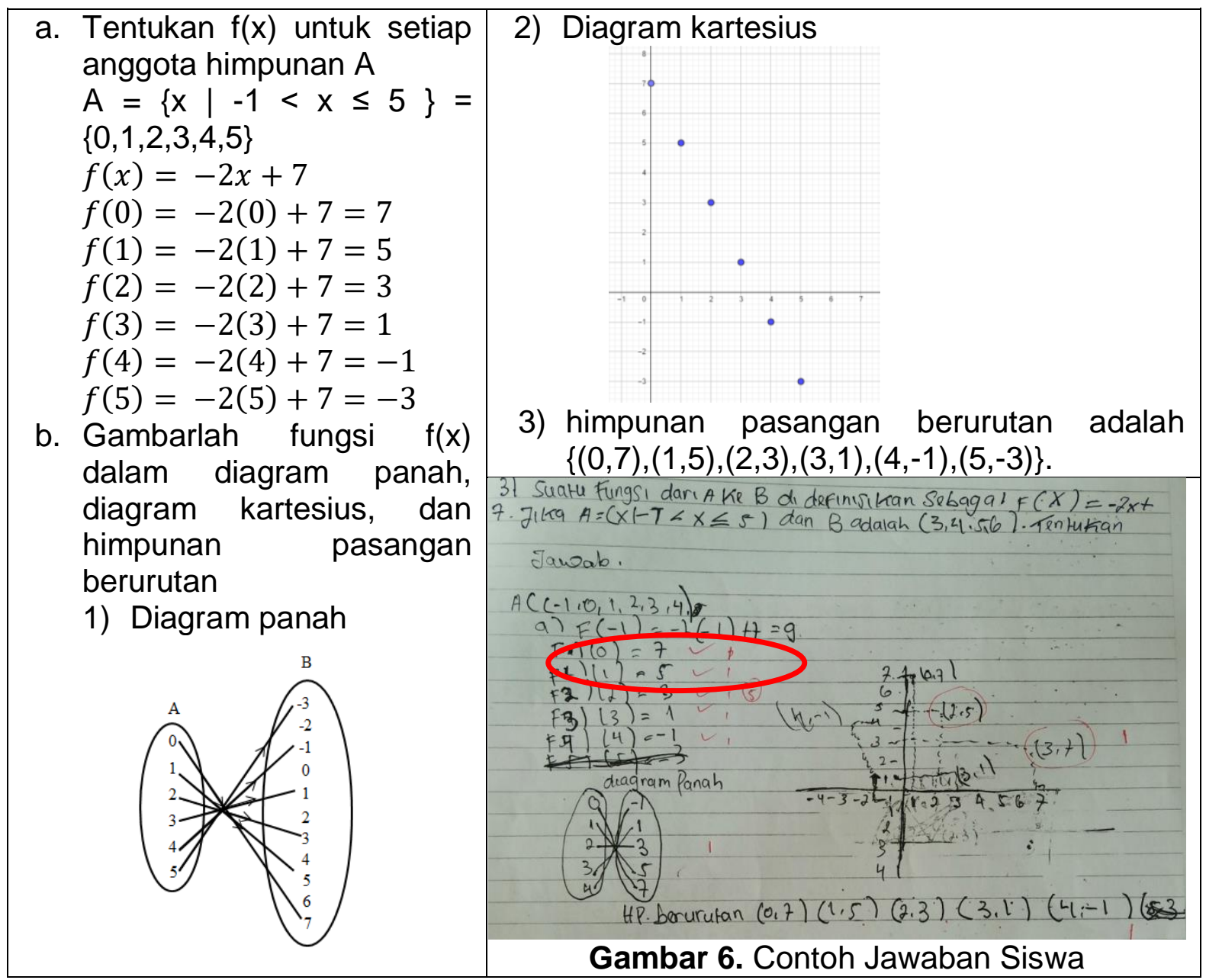

Berdasarkan gambar 6 tersebut dapat dilihat bahwa siswa tersebut melakukan kesalahan konsep, dimana siswa salah dalam menjabarkan anggotaanggota dari himpunan A. Seharusnya 5 termasuk anggota himpunan A tetapi siswa tidak menuliskannya. Hal ini disebabkan siswa tidak paham akan tanda " $\leq 5$ ", siswa menganggap tanda tersebut hanya "kurang dari 5" yang artinya 5 tidak termasuk dalam anggota himpunan A. kesalahan ini mengakipatkan kesalahan- 
kesalahan berikutnya yaitu kesalahan dalam menggambarkan diagram panah dan diagram kartesius serta himpunan pasangan berurutan. Terlihat dari jawaban siswa yaitu anggota himpunan A tidak lengkap sehingga jawaban siswa tersebut salah.

Selanjutnya pada gambar diagram kartesius dapat dilihat siswa salah dalam menggambarkan titik-titik koordinatnya, hal ini disebabkan siswa belum paham dalam menentukan titik koordinatnya atau siswa belum bisa menggabarkan diagram kartesius. Kesalahan tersebut merupakan salah satu indikator dari kesaalahan prinsip. Untuk kesalahan operasi beberapa siswa salah dalam mensubtitusikan nilai pada fungsi yang diberikan.

\section{Kesalahan pada soal 4}

Sama halnya dengan soal 3 , pada soal 4 terbagi menjadi dua yaitu a dan b, namun keduanya saling berhubungan. Jika pertanyaan a dijawab dengan salah maka pertanyaan b juga ikut salah. Kesalahan siswa pada soal 4 yaitu terdapat 11 siswa yang melakukan kesalahan konsep atau jika dipersentasekan terdapat $41 \%$. Selanjutnya 16 siswa atau 59\% siswa melakukan kesalahan prinsip serta 19 siswa atau $70 \%$ siswa melakukan kesalahan operasi. Kesalahan-kesalahan tersebut dapat dilihat dari gambar salah satu jawaban siswa berikut:

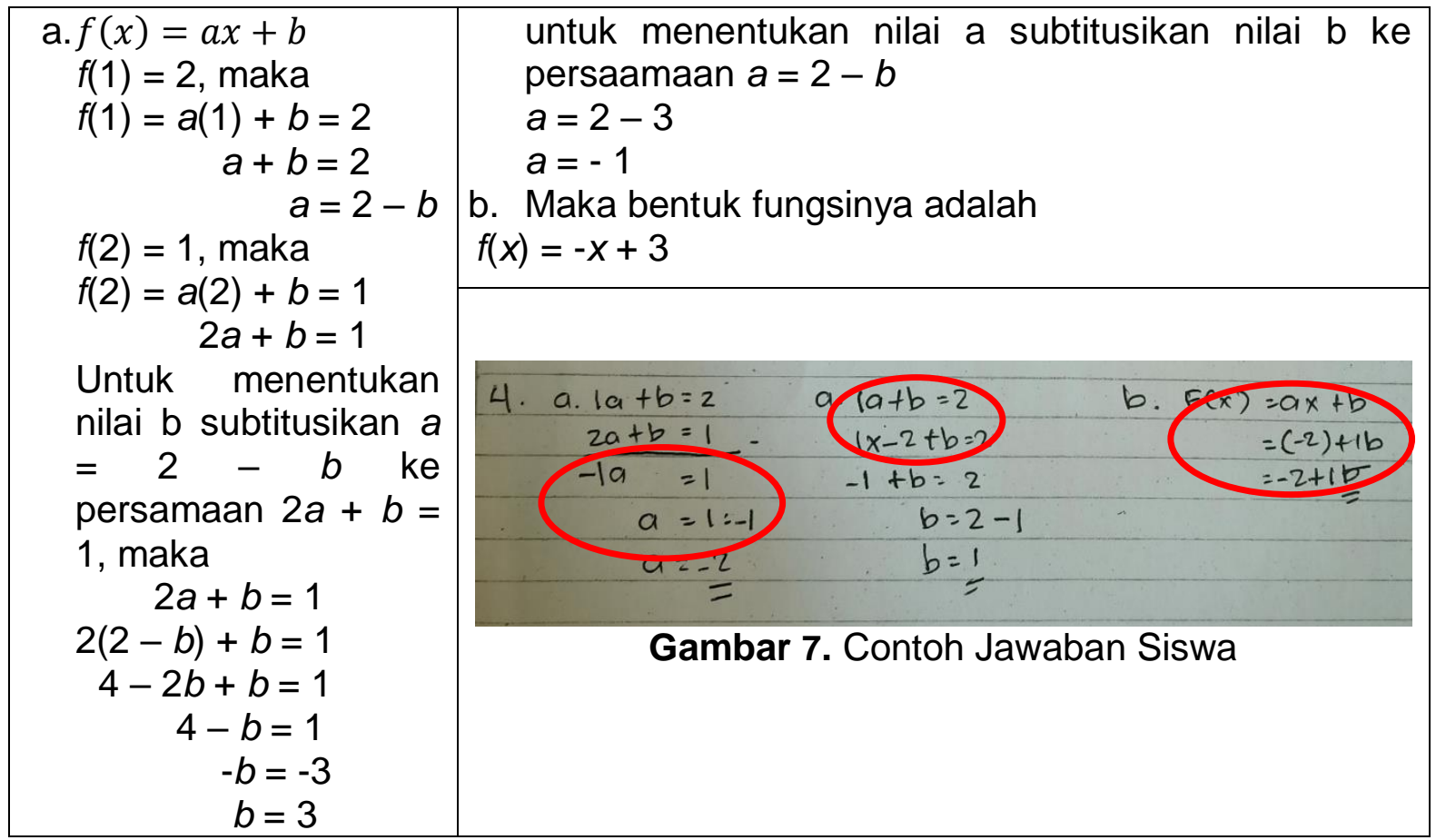


Berdasarkan gambar tersebut dapat dilihat siswa tersebut melakukan kesalahan operasi hitung seperti terlihat pada gambar di atas siswa menulis $1 a=1, a=1:-1, a=-2$. Seharusnya $-a=1, a=-1$. Dari jawaban siswa tersebut terlihat siswa belum paham akan konsep operasi aljabar, siswa menganggap koefisien pada a bisa dipindah ruaskan. Padahal koefisien merupakan angka yang melekat pada variabel, artinya ketika dipindah ruaskan variabel ikut dipindahkan. Selanjutnya karena siswa telah melakukan kesalahan pada jawaban sebelumnya hal ini mempengaruhi jawaban berikutnya. Terlihat pada gambar di atas, karena nilai a yang didapat siswa salah maka ketika siswa mengsubtitusikan nilai a pada persamaan ke 2 tentu saja nilai $b$ ikut salah dan begitu seterusnya.

\section{Kesalahan pada soal 5}

Pada soal 5 terdapat 17 siswa atau 63\% siswa melakukan kesalahan konsep. Siswa yang melakukan kesalahan prinsip yaitu 24 siswa atau $89 \%$. Sedangkan siswa yang melakukan kesalahan operasi yaitu 23 siswa atau $85 \%$. Kesalahankesalahan tersebut dapat dilihat dari gambar salah satu jawaban siswa berikut:

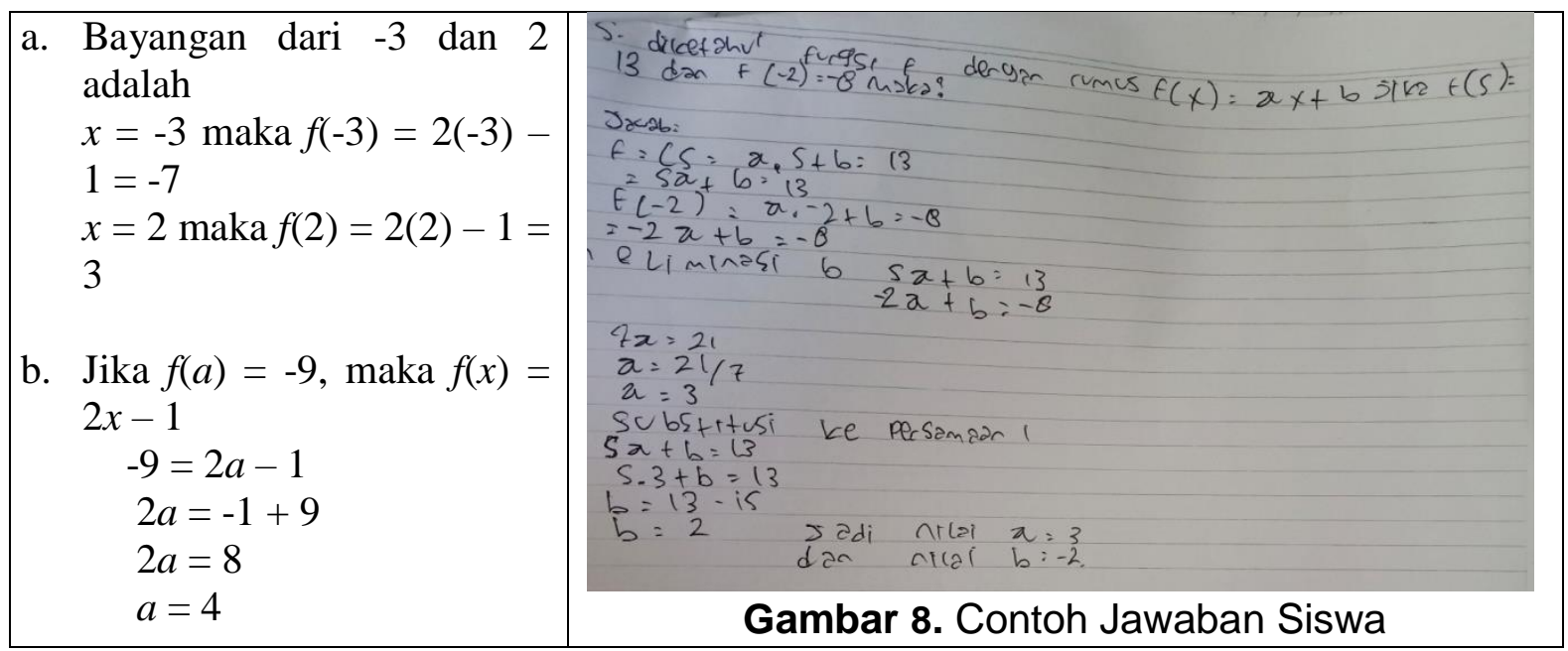

Berdasarkan gambar di atas siswa melakukan kesalahan prinsip, dimana siswa salah dalam menuliskan yang diketahui sehingga siswa salah dalam mencari nilai fungsi, sebagian siswa salah dalam mensubtitusikan nilai yang ditanyakan ke fungsi yang diketahui pada soal. Hal ini mungkin terjadi karena siswa tidak paham cara mencari nilai $f(x)$ jika nilai $x$ diketahui atau siswa tidak paham apa yang ditanyakan pada soal. Kesalahan yang siswa lakukan tersebut mengakibatkan kesalahan-kesalahan berikutya seperti kesalahan dalam operasi 
hitung, kesalahan dalam memanipulasi jalan pemecahan masalahnya, serta kesalahan dalam menyajikan data.

Mengacu dari pemaparan kesalahan yang dilakukan siswa pada setiap soal diatas, maka berikut persentase rata-rata kesalahan yang dilakukan siswa bedasarkan jenis kesalahan:

Tabel 1. Persentase Rata-Rata Kesalahan Siswa

\begin{tabular}{|l|c|}
\hline \multicolumn{1}{|c|}{ Jenis Kesalahan } & Persentase \\
\hline Konsep & $60 \%$ \\
\hline Prinsip & $51 \%$ \\
\hline Operasi & $63 \%$ \\
\hline
\end{tabular}

Berdasarkan tabel diatas, rata-rata kesalahan konsep yang dilakukan siswa yaitu $60 \%$, kesalahan prinsip $51 \%$ serta kesalahan operasi $63 \%$. Dari hasil tersebut setengah dari seluruh siswa melakukan kesalahan, artinya siswa mengalami kesulitan belajar yang megakibatkan mengalami kesalahan dalam mengerjakan soal.

\section{Pembahasan Peneltian}

Pada penelitian ini dilakukan analisis kesalahan yang terdiri dari kesalahan konsep, prinsip, dan operasi dalam menyelesaian soal relasi dan fungsi pada siswa kelas VIIIA SMP Negeri 4 Balai Jaya. Berdasarkan hasil analisis data pada kesalhan konsep siswa melakukan kesalahan dalam membedakan relasi dan bukan relasi begitu juga dalam membedakan fungsi dan buka fungsi. Siswa juga siswa salah dalam menjabarkan anggota-anggota dari himpunan A, disebabkan siswa tidak paham konsep dari simbol metematika.

Kesalahan menerapkan prinsip pada materi relasi meliputi: 1) kesalahan menyatakan relasi dengan diagram panah, 2) menyatakan relasi dengan grafik Cartesius. Hasil penelitian ini sejalan dengan hasil penelitian yang dilakukan oleh Ulifa (2014). Kesalahan menerapkan prinsip untuk menyatakan fungsi dengan diagram panah ada kaitannya dengan kesalahan yang dilakukan dalam menerapkan prinsip diagram panah pada relasi. Kesalahan memahami konsep relasi mengakibatkan kesalahan memahami konsep fungsi. Dikatakan demikian karena fungsi merupakan relasi yang mempunyai ciri-ciri khusus. Dengan kata 
lain, pemahaman tentang relasi merupakan kemampuan prasyarat untuk memahami konsep fungsi.

Kesalahan operasi yang siswa lakukan seperti kesalahan saat melakukan perhitungan dalam bentuk aljabar. Siswa tidak dapat mensubstitusi variabel bebas pada rumus fungsi dengan tepat karena masih belum dapat membedakan variabel bebas dan variabel terikat pada rumus fungsi dalam bentuk aljabar. Ketika siswa melakukan operasi hitung yang melibatkan suku-suku aljabar, siswa tidak meperhatikan suku-suku yang sejenis dan tidak sejenis melainkan langsung megoperasikan suku-suku tersebut. Hal ini disebabkan karena siswa belum terampil dan belum menguasai operasi aljabar. Seperti hasil penelitian Paladang (2018) bahwa faktor penyebab terjadinya kesalahan keterampilan proses yang paling sering terlihat adalah kurangnya penguasaan siswa terhadap materi operasi hitung bentuk aljabar. Ketika mengerjakan operasi hitung yang memiliki variabel, kadang ada yang mengabaikan variabelnya atau bahkan menghilangkannya. Ketika ditanyakan mengenai materi aljabar yang telah dipelajari sebelumnya, siswa mengaku sudah lupa bahkan menyatakan bahwa materi tersebut tidak ada hubungannya dengan materi fungsi yang sedang dipelajari.

\section{SIMPULAN}

Berdasarkan dari analisis yang telah peneliti lakukan maka dapat disimpulkan rata-rata kesalahan konsep yaitu $60 \%$, kesalahan prinsip yaitu $51 \%$ dan kesalahan operasi yaitu $63 \%$. Kesalahan yang paling banyak terjadi adalah kesalahan konsep dan kesalahan operasi. Siswa belum mampu menyajikan relasi dengan benar menggunakan diagram panah, diagram kartesius dan himpunan pasangan berurutan. Siswa juga masih kesulitan membedakan relasi, fungsi, dan tidak keduanya. Pada materi fungsi, penggunaan langkah-langkah yang dilakukan siswa kurang tepatsekaligus belum mampu menganalisis apakah suatu fungsi merupakan korespondensi satu-satu sehingga dapat dikatakan secara keseluruhan siswa belum menguasai materi fungsi dengan baik.

Faktor penyebab terjadinya kesalahan yang dilakukan oleh siswa dalam mengerjakan soal matematika pada materi relasi dan fungsi adalah siswa tidak teliti, siswa tidak tidak bisa membedakan relasi dan fungsi, tidak mengerti makna 
simbol dan lupa cara membaca simbol. Selain itu, terdapat simbol-simbol tertentu pada soal yang tidak dimengerti dan dimaknai dengan tepat oleh siswa, misalnya himpunan pasangan berurutan dan rumus fungsi, siswa lupa rumus yang harus digunakan dan terburu-buru saat menuliskan rumus, seringkali salah memaknai simbol, dan masih kurang menguasai materi prasyarat yaitu operasi hitung bentuk aljabar.

\section{DAFTAR PUSTAKA}

Amir, M. F. (2015). Analisis Kesalahan Mahasiswa PGSD Universitas Muhammadiyah Sidoarjo Dalam Menyelesaikan Soal Pertidaksamaan Linier. Jurnal Edukasi. 1(2), 131-145.

Anonim. (2007). Kamus Besar Bahasa Indonesia. Jakarta: Depdikbud.

Hastari, C. H. (2018). Analisis Kesulitan Soal Matematika Ditinjau dari Kecerdasan Emosional Mahasiswa di Kabupaten Tulung Agung. JNPM (Jurnal Nasional Pendidikan Matematika). 4(1), 180-196.

Hudojo, H. (2005). Pengembangan Kurikulum Dan Pembelajaran Matematika. Jakarta: Universitas Negeri Malang.

Jarmita, N. (2015). Kesulitan Pemahaman Konsep Matematis Siswa Dalam Pembelajaran Matematika Di Kelas Awal Sekolah Dasar. PIONIR (Jurnal Pendidikan). 4 (2), 1-16.

Lely, M., Putra, Z. H., \& Syahrilfuddin, S. (2020). Fifth Grade Students' Creative Thinking in Solving Open-Ended Mathematical Problems. Journal of Teaching and Learning in Elementary Education, 3(1), 58-68.

Ni'mah, R. D. (2009). Analisis Kesalahan Siswa dalam Menyelesaikan Soal Matematika Pokok Bahasan Garis Lurus. Skripsi tidak Diterbitkan. Malang: Universitas Negeri Malang.

Paladang, K. K, Indriani, S, Dirgantoro, K. P. S. (2018). Analisis Kesalahan Siswa Kelas Viii Slh Medan Dalam Mengerjakan Soal Matematika Materi Fungsi Ditinjau Dari Prosedur Newman [Analyzing Students' Errors In Solving Mathematics Problems In Function Topics Based On Newman's Procedures In Grade 8 At Slh Medan]. JOHME: Journal of Holistic Mathematics Education. 1(2), $93-103$ 
Sugiyono. (2005). Memahami Penelitian Kualitatif. Bandung: CV. Alfabeta.

Sulistyaningsih, A., \& Rakhmawati, E. (2017). Analisis Kesalahan Siswa Menurut Kastolan dalam Pemecahan Masalah Matematika. Seminar Matematika dan Pendidikan Matematika Universitas Negeri Yogyakarta, 123-130.

Susanto, A. (2016). Teori Belajar \& Pembelajaran di Sekolah Dasar. Jakarta: Prenadamedia Group.

Syafitri, R., Putra, Z. H., Noviana, E. (2020). Fifth Grade Students' Logical Thinking in Mathematics. Journal of Teaching and Learning in Elementary Education, 3(2), 157 - 167.

Ulifa, H.S. 2014. Hasil Analisis Kesalahan Siswa Dalam Menyelesaikan Soal Matematika Pada Materi Relasi. Sidoarjo. STKIP PGRI.

Wijaya, A. \& Masriyah. (2012). Analisis Kesalahan Siswa dalam Menyelesaikan Soal Cerita Materi Sistem Persamaan Linear Dua Variabel. Surabaya: FMIPA UNESA. 